Карынбаева О. В., Шкляр Н. В.

O. V. Karynbaeva, N. V. Shklyar

ПОВЫШЕНИЕ КОМПЕТЕНТНОСТИ ПЕДАГОГОВ-ДЕФЕКТОЛОГОВ

В УСЛОВИЯХ ДОПОЛНИТЕЛЬНОГО ПРОФЕССИОНАЛЬНОГО ОБРАЗОВАНИЯ

\title{
IMPROVING THE SKILLS OF SPECIAL EDUCATION TEACHERS IN TERMS OF ADDITIONAL PROFESSIONAL EDUCATION
}

Шкляр Наталья Валерьевна - кандидат психологических наук, доцент, доцент кафедры коррекционной педагогики, психологии и логопедии Приамурского государственного университета имени ШоломАлейхема (Россия, Биробиджан). E-mail: kor.ped@mail.ru.

Ms. Natalya V. Shklyar - PhD in Psychology, Associate Professor, Department of Correctional Pedagogy, Psychology and Speech Pathology, Sholem Aleichem Amur Region State University (Russia, Birobidzhan). E-mail: kor.ped@mail.ru.

Карынбаева Ольга Владимировна - старший преподаватель кафедры коррекционной педагогики, психологии и логопедии федерального Приамурского государственного университета имени Шолом-Алейхема (Россия, Биробиджан) E-mail: olgavlad11@mail.ru.

Ms. Olga V.Karynbaeva - Senior Lecturer, Department of Correctional Pedagogy, Psychology and Speech Pathology, Sholem Aleichem Amur Region State University (Russia, Birobidzhan). E-mail: olgavlad11@mail.ru.

Аннотация. В статье рассматривается повышение профессиональной компетентности педагоговдефектологов в процессе дополнительного профессионального образования. Предлагаются основные концептуальные, содержательные и практические аспекты модульной системы дополнительного профессионального образования педагогов-дефектологов.

Summary. The article discusses the increase of professional competence of special education teachers in the process of additional professional education. The basic conceptual, substantive and practical aspects of the modular system of additional professional education of teachers in special education.

Ключевые слова: профессиональная компетентность, педагоги-дефектологи, дополнительное профессиональное образование, профессиональная переподготовка, модульная система.

Key words: professional competence, teachers, speech pathologists, continuing professional education, professional retraining, modular system.

\section{УДК 371.1}

Современный этап развития системы дополнительного профессионального образования характеризуется переоценкой содержания, форм и технологий, системы повышения квалификации и профессиональной переподготовки педагогов. Государственной программой Российской Федерации «Развитие образования» на 2013-2020 годы выдвигаются основополагающие принципы этой системы: сочетание общефедеральных подходов с широкой инициативой местных органов управления образованием, непрерывность повышения квалификации на протяжении всего периода педагогической деятельности, согласованность и преемственность функционирования различных звеньев системы повышения квалификации, опережающий характер повышения квалификации с учетом перспектив развития образовательной системы, достижений педагогической науки и актуального педагогического опыта [2].

Для выполнения задач по внедрению новаций в образовательный процесс педагог должен обладать достаточно высоким уровнем профессиональной компетентности. Профессиональная компетентность педагога-дефектолога как сложное функциональное образование становится центральным объектом государственной политики, что выражается в социальном заказе по подготов- 
ке педагога-дефектолога высокого уровня, способного активно содействовать реализации образовательных проектов национального масштаба.

В связи с чем особую актуальность приобретает совершенствование и обновление системы дополнительного профессионального образования в процессе реализации компетентностного подхода, нацеленного сегодня на формирование практически применимых комплексных навыков, умений и знаний.

Теоретико-методологическую основу разработки проблемы повышения профессиональной компетентности специалистов, работающих с детьми с ограниченными возможностями здоровья, составили теории профессиональной подготовки педагогических кадров (В. А. Сластенин, В. Э. Тамарин, В. В. Краевский и др.); концепция личностно-развивающего подхода к изучению профессионального труда учителя (В. А. Ливитан, Л. М. Митина, Э. Р. Саитбаева и др.); концепция формирования личностных и профессиональных качеств педагога (А. Д. Азбукин, В. П. Кащенко, Н. М. Назарова и др.); теория деятельностного подхода к построению системы переподготовки педагогов (А. Н. Леонтьев).

Обновление форм организации процесса обучения педагогов в системе дополнительного образования должно происходить при качественном кадровом сопровождении, и это значит, что должна быть пересмотрена система подготовки, переподготовки и повышения квалификации педагогов.

По мнению В. А. Сластенина, Е. Н. Шиянова и других дополнительное профессиональное образование выполняет социально-педагогические функции: акмеологическую, сервисную, диагностическую, компенсаторную, инновационную, прогностическую, специализирующую, консультативную. Рассмотрим реализацию данных функций в системе дополнительного профессионального образования [13].

С одной стороны, дополнительное профессиональное образование выступает как ступень профессионально-личностного развития, с другой стороны - как процесс и результат саморазвития профессиональной субъектности и креативности, обогащения профессиональной культуры личности новыми качествами, позволяющими подняться до высокого уровня профессионализма.

Организация обучения педагогов по дополнительным образовательным программам должна соответствовать основным требованиям личностно-ориентированного образования. В этом случае ведущая роль в обучении слушателей курсов должна отводиться деятельностному подходу, направленному на обеспечение возможности для обучающегося в его собственной деятельности.

По мнению Э. М. Никитина одной из важнейших задач и результатом реформирования федеральной системы дополнительного образования педагогических работников должно стать появление педагога нового типа, способного к использованию инновационных форм и методов обучения [11].

Л. Н. Макарова подчеркивает, что существующая система дополнительного образования требует значительных изменений, которые, по мнению автора, заключаются в поиске путей решения организации образовательного процесса потребителей с учетом их индивидуальных потребностей, направленных на развитие профессиональной компетентности обучающегося [9].

Понятие «профессиональная компетентность» рассматривалось многими специалистами (К. А. Абульханова-Славская, В. А. Адольф, Н. М. Борытко, А. А. Дубасенюк, Э. Ф. Зеер, Л. М. Митина, А. К. Маркова, И. Н. Пономарева, В. А. Сластенин и другие).

А. А. Дубасенюк, обобщив различные подходы зарубежных и отечественных исследователей к определению сущности компетентности, приходит к выводу о том, что это интегральная характеристика личности, определяющая ее способность решать проблемы и типичные задачи, которые возникают в реальных жизненных ситуациях, в разных сферах деятельности на основе использования знаний, учебного и жизненного опыта в соответствии с усвоенной системой ценностей [3].

По мнению А. К. Марковой профессиональная компетентность - это способность и умение самостоятельно и ответственно выполнять определенные трудовые функции, заключающиеся в результатах труда человека [10]. 
Карынбаева О. В., Шкляр Н. В.

ПОВЫШЕНИЕ КОМПЕТЕНТНОСТИ ПЕДАГОГОВ-ДЕФЕКТОЛОГОВ В УСЛОВИЯХ ДОПОЛНИТЕЛЬНОГО

ПРОФЕССИОНАЛЬНОГО ОБРАЗОВАНИЯ

Н. М. Борытко рассматривает компетентность как единство теоретической и практической готовности педагога к выполнению профессиональных функций [1].

Одним из наиболее распространенных способов повышения профессиональной компетентности является повышение квалификации, цель которого - оптимизация педагогического процесса, профессиональный рост и самосовершенствование педагогов.

В настоящее время в процессе подготовки, переподготовки и повышения квалификации педагогов особое внимание уделяется модульному обучению.

Теория модульного обучения изложена в работах В. М. Гараева, Б. Гольдшмида, М. Гольдшмида, М. В. Драча, Е. И. Дурко, В. В. Карпова, О. К. Клоповой, Н. С. Крючкиной, С. И. Куликова, И. Б. Сенновского, Ю. Ф.Тимофеевой, П. И. Третьякова, О. Г. Проворовой, Н. А. Русакова, П. А. Юцявичене и других.

М. В. Драч подчеркивает, что содержание модуля должно отвечать требованиям последовательности, целостности, компактности и автономности. Следовательно, содержание образования предполагает компоновку материала учебной дисциплины вокруг ее базовых понятий и методов, систематичность и логическую последовательность изложения учебного материала, целостность и практическую значимость содержания, наглядное представление учебного материала [4].

О. К. Клопова считает такое обучение эффективным, т.к. модуль заключает в себе четкое дозирование учебного материала, логическую последовательность действий для слушателей, возможность усваивать материал в удобное для них время [7].

П. А. Юцявичене определяет модуль как «блок информации, включающий в себя, логически завершенную единицу учебного материала, целевую программу действий и методическое руководство, обеспечивающее достижение поставленных дидактических целей» [12].

Н. С. Крючкина и Н. А. Русакова указывают, что модуль должен завершаться соответствующей формой контроля знаний, умений и навыков, сформированных в результате овладения обучаемым данного модуля [8].

В Приамурском государственном университете имени Шолом-Алейхема, в частности на факультете педагогики и психологии - центре педагогического образования, значительное внимание уделяется переподготовке психолого-педагогических кадров. Это направление деятельности отражено в работах О. В. Карынбаевой [5], [15], Н. В. Корякиной [6], Н. В. Шкляр [14], [15] и других педагогов.

Силами профессорско-преподавательского состава кафедры коррекционной педагогики, психологии и логопедии систематически осуществляется реализация профильных программ повышения квалификации и профессиональной переподготовки педагогов образовательных учреждений города Биробиджана, Еврейской Автономной области и других регионов.

Повышение профессиональной компетентности педагогов осуществляется на научнопрактических семинарах, в процессе курсов повышения квалификации и переподготовки.

В основу проектирования модульной системы дополнительного профессионального образования были положены следующие принципы: гуманизации образования, последовательности, научности, сознательности, систематичности, творческой активности, модульности обучения, совместного и индивидуального обучения.

Нами была разработана и апробирована модульная система повышения профессиональной компетентности педагогов-дефектологов в условиях дополнительного профессионального образования.

Первый модуль предусматривал организацию и проведение научно-практических семинаров различного уровня по следующим темам: «Актуальные проблемы и перспективы психологопедагогического сопровождения детей с ограниченными возможностями здоровья в образовательном процессе», «Психолого-педагогические инновации в сопровождении образования детей с ограниченными возможностями здоровья», «Обобщение опыта психолого-педагогического сопровождения детей с ограниченными возможностями здоровья», «Пути повышения профессиональной компетентности специалистов в условиях сопровождения детей с ограниченными возможностями здоровья» и др. 
Целями семинаров явились: повышение научно-методического уровня и педагогического мастерства педагогов-дефектологов, вооружение знаниями о сущности и специфике профессиональной педагогической деятельности в контексте модернизации образования, обеспечение мотивационного и организационного механизмов личностного и профессионального саморазвития педагогов-дефектологов.

При реализации данного модуля применялись разнообразные формы работы со слушателями: открытые занятия, уроки (демонстрация видеофрагментов) с целью обобщения накопленного педагогического опыта; проектирование и моделирование образовательного процесса, решение педагогических ситуаций.

Участие в научно-практических и учебно-методических семинарах для педагогов-практиков образовательных организаций способствовало обмену мнениями в контексте проблемы педагогической интеграции, решению актуальных проблем современного образования.

Второй модуль был направлен на проведение курсов повышения квалификации педагоговдефектологов: «Современные подходы и образовательные технологии в работе с детьми с ограниченными возможностями здоровья в общеобразовательных организациях» (36 ч), «Психологопедагогическое сопровождение дошкольников с ограниченными возможностями здоровья» (36 ч), «Учитель-логопед в современном образовательном пространстве» (36 ч), «Методология и технологии реализации инклюзивного образования учащихся с ограниченными возможностями здоровья в условиях внедрения ФГОС» (72 ч), «Профессиональная готовность педагогов к деятельности в условиях инклюзивной практики» (72 ч).

Содержание программ курсов повышения квалификации и профессиональной переподготовки планировались в соответствии с образовательными запросами слушателей.

Перечень инвариантных тем при курсовом обучении определялся с учетом обновления и совершенствования профессиональной компетентности педагогов-дефектологов с целью предупреждения устаревания профессиональных знаний, а также поддержания и дальнейшего развития уровня их профессионализма. Выбор тем для индивидуальных образовательных программ слушателей проводился дифференцированно с учетом выявленного дефицита в развитии профессиональной компетентности, типа и вида образовательного учреждения, являвшегося местом работы слушателя, контингента детей, особенностей их сопровождения.

Третий модуль - разработка и внедрение программ профессиональной переподготовки: «Профессиональная готовность педагогов к инновациям в системе образования детей с ограниченными возможностями здоровья» (250 ч), «Культура психолого-педагогического сопровождения детей с ограниченными возможностями здоровья в условиях современного образования» (300 ч), «Основы специального (дефектологического) образования» (506 ч). Данные программы разработаны с учетом социального заказа общества и потребностей потребителей.

Одним из показателей профессиональной компетентности педагогов является их способность к самообразованию, поэтому данной форме мы уделяли особое внимание. При планировании работы учитывались трудности и потребности педагогов. Для этого предварительно проводились индивидуальные консультации, беседы, наблюдения на уроках и в процессе организации воспитательной работы с последующим анализом. В работе с педагогами предусматривались такие формы, как анализ психолого-педагогической литературы с последующей подготовкой докладов и выступлением на научно-практических мероприятиях, посещение тренингов, уроков коллег, анализ собственных уроков.

Участие педагогов в программах профессиональной переподготовки способствовало развитию их исследовательской компетенции, предполагающей способность изучать, проектировать, реализовывать процесс обучения с использованием инновационных технологий.

Разнообразные формы и методы работы с педагогами позволили оказаться им в ситуациях, требующих от них самоопределения, обозначения своих профессиональных проблем и трудностей, поиска путей их разрешения, что способствовало их переходу из объекта профессионального обучения в субъект повышения своей компетентности. 
Карынбаева О. В., Шкляр Н. В.

ПОВЫШЕНИЕ КОМПЕТЕНТНОСТИ ПЕДАГОГОВ-ДЕФЕКТОЛОГОВ В УСЛОВИЯХ ДОПОЛНИТЕЛЬНОГО

ПРОФЕССИОНАЛЬНОГО ОБРАЗОВАНИЯ

Многоэтапный характер, дифференцированный и индивидуальный подходы к организации и реализации программ профессиональной переподготовки предполагали использование разнообразных педагогических ситуаций и задач, лекционных и практических занятий, тренингов и консультативной деятельности в зависимости от уровня развития профессиональной компетентности педагогов-дефектологов.

Таким образом, спроектированная и апробированная модульная система окажет существенную помощь в совершенствовании и повышении профессиональной компетентности педагогов-дефектологов.

\section{ЛИТЕРАТУРА}

1. Борытко, Н. М. Профессионально-педагогическая компетентность педагога // Интернет-журнал «Эйдос». 2007. 30 сентября. http://www.eidos.ru/journal/2007/0930-10.htm. (Дата обращения 27.06.2015).

2. Государственная программа Российской Федерации «Развитие образования» на 2013-2020 годы. - М., 2013.

3. Дубасенюк, А. А. Особенности профессионального становления учителя в контексте компетентностного подхода / А. А. Дубасенюк // Вектор науки ТГУ. - 2010. - №2 (2). - С. 38-42.

4. Драч, М. В Учебный модуль по трехмерному моделированию как обязательный компонент проектноконструкторской подготовки в вузе [Электронный ресурс] / М. В. Драч. - Режим доступа: http://conf.sfukras.ru/sites/mn2012/thesis/s013/s013-002.pdf (Дата обращения 29.07.2015).

5. Карынбаева, О. В. Повышение профессиональной компетентности педагогов в области интегрированного обучения детей с ограниченными возможностями здоровья / О. В. Карынбаева // Вектор науки Тольяттинского государственного университета. Серия: Педагогика и психология. - 2013. - № 1(12). - С. 102-105.

6. Корякина, Н. В. Педагоги-дефектологи о необходимости повышения профессиональной компетентности в процессе методической работы / Н. В. Корякина // Постулат. - 2016. - № 4. - С. 20.

7. Клопова, О. К. Проектирование и реализация модульной технологии повышения квалификации менеджеров по персоналу организаций малого и среднего бизнеса: дис. ... канд. пед. наук: 13.00 .08 / Клопова Ольга Константиновна. - Тольятти, 2004. - 151 с.

8. Крючкина, Н. С. Реализация модульной системы обучения на основе новых информационных технологий / Н. С. Крючкина, Н. А. Русакова. - Кемерово: ИНТ, 2007. - 420 с.

9. Макарова, Л. Н. Моделирование системы повышения квалификации преподавателей педвузов и колледжей / Л. Н. Макарова // Педагогика. - 2004. - № 3. - С. 60-68.

10. Маркова, А. К. Психология профессионализма / А. К. Маркова. - М.: Мысль, 1999. - 308 с.

11. Никитин, Э. М. Федеральная система повышения квалификации работников образования: учеб. пособие / Э. М. Никитин. - М.: Просвещение, 1995. - 194 с.

12. Принципы модульного обучения: методическая разработка для преподавателей / сост. О. Г. Провоторова. - Красноярск: Изд-во Краснояр. гос. ун-та, 2006. - 32 с.

13. Сластенин, В. А. Педагогика: учеб. пособие для студентов педагогических учебных заведений В. А. Сластенин, И. Ф. Исаев, А. И. Мищенко, Е. Н. Шиянов. - М.: Школа-Пресс, 1997. - 512 с.

14. Шкляр, Н. В. Подготовка и переподготовка психолого-педагогических кадров в региональном вузе / Н. В. Шкляр // Высшее образование в России. - 2015. - № 3. - С. 120-127.

15. Шкляр, Н. В. Модульное обучение педагогов для работы с детьми с ограниченными возможностями здоровья в условиях инклюзивного образования / Н. В. Шкляр, О. В. Карынбаева // Ученые записки Комсомольского-на-Амуре государственного технического университета. Науки о человеке, обществе и культуре. 2016. - T. 2. № 1(25). - C. 24-28. 